\title{
Interspecies reactivity and intraspecies
} specificity of

\section{antilymphoid globulin}

I phocyte serum is highly specific in that (a) it lyses or agglutinates equally well the white cells from all members of the species which provided the immunizing lymphoid tissue ${ }^{3}$ and (b) that it does not react with the white cells from other species. ${ }^{1,3,4,6}$ The foregoing concepts were based upon studies employing anterisera of relatively low titer.

These questions have been re-examined with antidog- and antihuman-lymphoid globulin of high titer raised in horses with repeated subcutaneous immunization with lymph node, thymus, and spleen tissue. ${ }^{5}$ It has been found that the white cells of individuals within the species population, against which the antibodies were directed, were variably affected by the immune globulin. Furthermore, it has been shown that there is not an absolute species specificity inasmuch as some reactivity against the white cells of at least seven widely divergent species is present in either antidog- or antihuman-lymphoid globulin.

\section{METHODS}

Serum was collected from horses which had been immunized against human or dog Aided by Grants AM 06283, AM 06344, HE 07735. AM 07772, AI 04152. FR 00051, and FR 00064 from the United States Public Health Service.

Received for publication Jan. 31, 1967.
C. W. PUTNAM, B.A.

N. KASHIWAGI, M.D.

Y. IWASAKI, M.D.

P. I. TERASAKI, PH.D.

T. L. MARCHIORO, M.D.

T. E. STARZL, M.D., Ph.D.

DENVER, COLO., AND LOS ANGEles, CALIF.

From the Department of Surgery, University of

Colorado School of Medicine and the Denver

Veterans Administration Hospital, and the

Department of Surgery, UCLA Medical Center

lymphoid tissue, and it was absorbed first against pooled red cell pack and then with the pooled serum of the lymphoid donor species. Details of these techniques and the methods of the subsequent globulin extraction are described elsewhere. ${ }^{5}$ The antihuman globulin was from a horse which had received lymphoid tissue from 9 donors. The antidog globulin was a pooled product from 4 horses which had from 10 to 30 lymphoid donors. In all cases the original serum was initially heated at $36^{\circ}$ C. for 30 minutes.

Titers of leukoagglutinin activity of both antidog and antihuman globulin were determined by a modification of the methods of Dausset $^{2}$ and Payne. ' White cells for testing were prepared by drawing $10 \mathrm{ml}$. blood into $1 \mathrm{ml}$. of 5 percent EDTA solution. The human, monkey, pig, and dog specimens were mixed with $2 \mathrm{ml} .6$ percent dextran for 30 minutes to sediment the red cells, and the supernatant of leukocyte-rich plasma was removed and centrifuged for 10 minutes at 800 r.p.m. The supernatant of plasma was removed and centrifuged at 3,000 r.p.m. for 10 minutes to eliminate the platelets. The platelet-free plasma was now employed to resuspend the white cells in a concentration of 5,000 cells per cubic millimeter. Since 
dextran did not efficiently sediment cow, sheep, guinea pig, or rabbit red cells, the red cells were removed by centrifugation after which the buffy coat and plasma were processed as described previously. Equal volumes $(0.1 \mathrm{ml}$.) of resuspended cells were added to serial twofold dilutions of $0.1 \mathrm{ml}$. of the reconstituted globulin using buffered saline as a diluent. After incubation at $37^{\circ} \mathrm{C}$. for 1 hour, the agglutination was read by the criteria of Payne as the reciprocal of the highest dilution which gave 2 plus agglutination.

Alternatively, the effect upon human leukocytes of the antihuman-lymphoid globulin was quantitated by one of us (Dr. Terasaki) using a previously described micromethod to assay lymphocyte cytotoxicity. ${ }^{8}$

In additional experiments, the leukoagglutinin titers of the two types of globulin were determined before and after a variety of

Table I. Cytotoxicity and agglutinin titers against human leukocytes of one batch of antihuman-lymphoid globulin

\begin{tabular}{c|c|c}
\hline $\begin{array}{c}\text { Leukocyte } \\
\text { donor }\end{array}$ & $\begin{array}{c}\text { Leukoagglutinin } \\
\text { titer }\end{array}$ & $\begin{array}{c}\text { Cytotoxic } \\
\text { titer }\end{array}$ \\
\hline 1 & $1: 4,096$ & $1: 100$ \\
2 & $1: 4,096$ & $1: 7,500$ \\
3 & $1: 4,096$ & $1: 7,500$ \\
4 & $1: 4,096$ & $1: 7,500$ \\
5 & $1: 4,096$ & $1: 37,500$ \\
6 & $1: 8,192$ & $1: 37,500$ \\
7 & $1: 8,192$ & $1: 37,500$ \\
8 & $1: 8,192$ & $1: 187,500$ \\
9 & $1: 16,384$ & $1: 187,500$ \\
10 & $1: 16,384$ & \\
\hline
\end{tabular}

*Different panels of donors were used for the leukoagglutination and cytotoxicity studies. additional absorptions, carried out as mentioned below. Red cell absorption was done three times at $37^{\circ} \mathrm{C}$. for 30 minutes and then at $4^{\circ} \mathrm{C}$. for 1 hour with pooled red cell pack from 3 donors in equal volume to that of the reconstituted globulin. White cell absorption was under similar conditions.

\section{RESULTS}

Intraspecies variability. The antidog-lymphoid globulin was tested against a panel of 4 canine white cell donors. The titers in the individual tests were $1: 1,024 ; 1: 1,024$; $1: 2,048$; and $1: 4,096$.

A similar variability of antihuman-lymphoid globulin was noted (Table I) where the leukoagglutinating titers were obtained against the white cells of 10 normal humans. The values ranged from 1: 4,096 to 1:16, 384. Furthermore, an even greater variability was present in the titers of cytotoxic antibodies determined against a similar panel of 9 (Table I).

Interspecies cross-reactivity. The immune globulin had a weak leukoagglutinating action against the white cells of other species than that used for provision of antigen ( $\mathrm{Ta}$ ble II). Thus the antidog globulin, which had a titer of 1:2,048 against dog leukocytes, also agglutinated human white cells at a dilution of 1:16. Conversely, the high titer-antihuman globulin agglutinated the leukocytes of dogs as well as those of widely divergent species, the most pronounced effect being with the white cells of African green monkeys (Table II).

Control experiments showed that a non-

Table II. Cross-species reactivity of antihuman- and antidog-lymphoid globulin

\begin{tabular}{l|l|l}
\hline Species leukocytes tested* & Horse antidog globulin & Horse antihuman globulin \\
\hline Human (3) & $1: 16,1: 16,1: 16$ & $1: 4,096 ; 1: 8,192: 1: 16,384$ \\
Dog (3) & $1: 2,048 ; 1: 1,024 ; 1: 1,024$ & $1: 128,1: 64,1: 256$ \\
African green monkey (3) & $1: 32,1: 16,1: 16$ & $1: 2,048 ; 1: 1,024 ; 1: 2,048$ \\
Cow (3) & $1: 32,1: 64,1: 128$ & $1: 8,1: 64,1: 16$ \\
Sheep (3) & $0,1: 4 ; 1: 8$ & $1: 64,1: 64,1: 128$ \\
Pig (3) & $0,1: 2,1: 2$ & $1: 2,1: 8,1: 4$ \\
Guinea pig (2) & $1: 32,1: 32$ & $1: 2,1: 4$ \\
Rabbit (2) & $1: 8,1: 8$ & $1: 64,1: 128$ \\
Horse (2) & 0,0 & 0,0 \\
\hline
\end{tabular}

*Either 2 or 3 individuals from each species were tested, as indicated. 
Table III. Effect on species cross-reactivity of absorption with sheep and bovine red cells*

\begin{tabular}{|c|c|c|c|}
\hline \multirow[b]{2}{*}{ Horse antihuman-lymphoid globulin } & \multicolumn{3}{|c|}{ Leukocytes } \\
\hline & Human & Sheep & Cow \\
\hline $\begin{array}{l}\text { Unabsorbed } \\
\text { Absorbed with sheep R.B.C. } \\
\text { Absorbed with bovine R.B.C. }\end{array}$ & $\begin{array}{l}1: 4,000 ; 1: 8,000 \\
1: 4,000,1: 4,000\end{array}$ & $\begin{array}{l}1: 64 \\
1: 32\end{array}$ & $\begin{array}{l}1: 16 \\
1: 16\end{array}$ \\
\hline
\end{tabular}

specific white cell toxin in the horse serum did not account for these results. The leukocytes of 2 normal horses were not agglutinated by the globulin used for testing (Table II).

Absorption experiments. Antidog and antihuman lymphoid globulin which weakly agglutinated sheep and/or cow leukocytes was absorbed with sheep or cow red cells pack (Table III). The interspecies leukoagglutinating titer was not significantly reduced with the sheep red cell absorption thereby eliminating the possibility that the crossreactions were due to antibodies in the immune globulin which reacted with EislerKagaya or Forssman antigens located in the white cells. Similarly, absorption with bovine red cells caused no change in the interspecies reaction.

In addition, antihuman and antidog lymphoid globulins which weakly cross-reacted with dog and human white cells were absorbed against dog and human cells, respectively (Table IV). The titers against the leukocytes of the original donor species were thereby reduced, and the interspecies crossagglutination was eliminated (Table IV).

\section{DISCUSSION}

It is apparent that both antihuman and antidog-lymphoid globulin do not equally affect the white cells from all individuals of the species used for immunization. The considerable variability was confirmed in two independent laboratories employing different techniques for determination of titer. The findings are probably due to differing antigenic constitutions of the leukocytes in the lymphoid donors. Under these circumstances
Table IV. The effect of absorption with dog and human red and white cells upon the cross-species leukoagglutinin titers

\begin{tabular}{l|l|c}
\hline \multicolumn{1}{c|}{ Globulin } & $\begin{array}{c}\text { Human } \\
\text { leuko- } \\
\text { cytes }\end{array}$ & $\begin{array}{c}\text { Dog } \\
\text { leuko- } \\
\text { cytes }\end{array}$ \\
\hline $\begin{array}{l}\text { Antihuman } \\
\quad \text { Unabsorbed } \\
\text { Absorbed with dog R.B.C. } \\
\quad \text { and W.B.C. }\end{array}$ & $1: 8,192$ & $1: 128$ \\
$\begin{array}{l}\text { Antidog } \\
\quad \text { Unabsorbed } \\
\quad \text { Absorbed with human } \\
\quad \text { R.B.C and W.B.C. }\end{array}$ & $1: 2,048$ & $1: 2$ \\
\hline
\end{tabular}

it would not be surprising to find some individual specificity of the subsequently tested serum products.

These observations have practical implications. They suggest that even with multiple tissue donors, a uniform representation of antigens was not achieved and that the resulting globulin could be more effective in some cases than in others if it were used therapeutically for its immunosuppressive qualities. As a consequence, it may prove necessary either to provide immunizing antigen from a very large number of donors or, alternatively, to select that globulin to be used for therapy on the basis of testing against the white cells of the subject to be treated. This problem is of course less apt to be significant in animal experiments using inbred lymphoid donors where a high degree of antigenic homogeneity is to be expected.

The demonstration of cross-reactivity is also an interesting observation which is presumed to be due to shared or similar antigens 
in the leukocytes of widely divergent species. This possibility appears to be supported by the results with various absorption procedures which further indicate that the shared antigens are not of the Forrsman or EislerKagaya variety.

\section{SUMMARY}

Horse antihuman and antidog antilymphocyte globulins were shown to possess leukoagglutinating antibodies when tested against the white cells from a number of other divergent species. In addition, the white cells of individuals within the species against which immunization was originally conducted were variably affected by the immune globulin. The latter observation suggests that these globulins could be more effective in some cases than in others if they were used therapeutically for their immunosuppressive qualities.

\section{REFERENCES}

1. Cruickshank, A. H.: Antilymphocytic serum, Brit. J. Exper. Path. 22: 126, 1941.
2. Dausset, J.: Technique for demonstrating leukocyte agglutination, in Russell, P. S., and Winn, H. J., editors: Histocompatibility testing, Washington, D. C., 1965, National Academy of Sciences, p. 147.

3. Gray, J. G., Monaco, A. P., and Russell, P. S.: Heterologous mouse antilymphocyte serum to prolong skin homografts, S. Forum 15: 142, 1964.

4. Gray, J. G., Monaco, A. P., Wood, M. L., and Russell, P. S.: Studies on heterologous antilymphocyte serum in mice. I. In vitro and in vivo properties, J. Immunol. 96: 217, 1966.

5. Iwasaki, Y., Porter, K. A., Amend, J., Marchioro, T. L., Zuhlke, V., and Starzl, T. E.: The preparation and testing of horse antidog and antihuman antilymphoid plasma or serum and its protein fractions, Surg. Gynec. \& Obst. 124: 1, 1967.

6. Metchnikoff, E.: Études sur la résorption des cellules, Ann. Inst. Pasteur 13: 737, 1899.

7. Payne, R.: An agglutination technique for the demonstration of leukocyte isoantigens in man, in Russell, P. S., and Winn, H. J., editors: Histocompatibility testing, Washington, D. C., 1965, National Academy of Sciences, p. 149.

8. Terasaki, P. I., and McClelland, J. D.: Microdroplet assay of human serum cytotoxins, Nature 204: 998, 1964. 